\title{
"KING AS A LAW GIVER" IN THE UR III DYNASTY"
}

\section{TOHRU MAedA**}

1 I have been studying changes in the development of royal titles from the Early Dynastic period to the Akkadian Dynasty in order to clarify the different stages of the Sumerian idea of kingship. (1) These studies have chiefly depended on an examination of contemporary source materials, such as royal inscriptions and administrative documents. These source materials are reliable for two reasons: Firstly, contemporary accounts were not influenced by later people's thoughts while these did affect works of historiography and literature from the Old Babylonian period downward. Secondly, the reasons for the legitimacy of kingship or the image of the ideal king in each period appeared directly in royal inscriptions, although these inscriptions were written either as dedications to the gods or for a king's self-glorification.

Conclusions of these previous studies are as follows:

(i) The royal title "king of the city Kiš (lugal-kiški)," which was held by the Sumerian rulers Mesannepada of Ur, Eannatum of Lagaš and Lugalkiginnedudu of Uruk, is not the same title as "king of KIS or king of kiššati (lugal-KIS)" held by the Akkadian rulers Sargon, Rimuš and Maništusu. The first title characterized a ruler's own personal greatness, such as one who was able to defeat the enemy in other lands, but it did not designate him as the overlord of Sumer and Akkade. It was used as a symbol of the mighty ruler who could exert his power during conflicts between city-states.

(ii) The very end of the Early Dynastic period and the first half of the Akkadian period cover the same stage in the development of the idea of kingship. "King of the Land (lugal-kalam-ma)" and "king of KIS (lugal-KIS)" are both titles expressing sovereignty over Sumer and Akkade, although the center of political power was shifting from the south to the north. The idea of kingship in this period was, in principle, to unify Sumer and Akkade, and to maintain peace and order in their domains under the protection of the god Enlil. The

* I intend in this paper to present part of the results of the study made under the 1984 Ministry of Education's Grant in Aid for Scientific Research.

* Associate Professor, Waseda University. 
image of a pious king before the gods was central to the idea of kingship. ${ }^{(2)}$

(iii) Through use of the title "king of the four regions (šar kibrätim arba'im)", Naram-Sin gained mastery over the barbarians in distant countries and excuted a policy of military expansion ordered by the goddess Inanna. He changed the idea of kingship from a pious king before the gods to the mighty king reigning over all people. Based on this, we can say that the stage of empire first emarged in the reign of Naram-Sin, and not in the reign of Sargon.

From the Ur III period onward, rulers repeatedly used royal titles which described the king's sovereignty over all the world, such as "king of the world (šar kiššati)", "king of Sumer and Akkade (lugal ki-en-gi-ki-uri)" and "king of the four regions (lugal an-ub-da-limmú-ba)".(3) "King of the four regions" of Ur III kings contrasted with Naram-Sin's title. The Ur III kings expressed sovereignty over the world through peace and order, and not through military expansion into distant countries. In the history of Mesopotamia, Ur III kings had a wider politico-geographical view of the world than that of Naram-Sin, and they regarded the distant countries as part of the regions controlled by the god Enlil.

For this reason, examination of the royal titles is no longer useful for clarifing the stages of the kingship from the Ur III period onward. In this study, therefore, I will rely on the law codes, written first in the Ur III period.

I will study what idea of kingship the function of the rulers who established the laws was based on, and how the meaning of níg-si-sá/mǐ̌arum changed between the Early Dynastic period and Ur III period.

2 There are examples in the prologue to the Lipit-Ištar law code and Hammurapi law code expressing that the gods gave the kingship to the ruler in order to establish justice:

$\mathrm{u}_{4}$-ba di-pi-it-ištar sipa-giš-tuk mu-pà-da nu-nam-nir-ra níg-si-sá kalamma gá-gá-dè i- ${ }^{\mathrm{d}}$ utu ha-lam-e-dè níg-erím níg-á-zi é-ba gi $_{4}$-gi ${ }_{4}$-dè ki-engi-ki-uri su-ba $\mathrm{du}_{10}$-ge-dè an-né den-líl-le di-pi-it-ištar nam-nun-kalamma-šè mu-un-pà-dè-eš-a-ba

"At that time, - Lipit-Ištar, the obedient shepherd whose name was given by Nunamnir - , in order to establish justice in the land, to banish grief, to turn back malevolence and wickedness into their houses, ${ }^{(4)}$ and to promote the welfare of the Sumerians and Akkadians, An and Enlil 
called Lipit-Ištar to the princeship of the land."

Lipit-Ištar law code: TCL XV 34, I 20-II 13

inumišu hammurapi rubâm na'dam pālih ili jâti

mišaram ina mätim ana šūpim raggam u șēnam ana hulluqim

dannum enšam ana la habālim kima đ̌̌amaš ana șalmät qaqqadim

wașim

mātim muwreurim

anum $u$ denlil ana šir niši tubbim šumi $i b b \bar{u}$

hammurapi rē'um nibit denlil anaku

"At that time Anum and Enlil named me,

to promote the welfare of the people,

me, Hammurapi, the devout, god-fearing prince,

to cause justice to prevail in the land,

to destroy the wicked and the evil,

that the strong might not opress the weak,

to rise like the sun over the black-headed (people),

and to light up the land.

Hammurapi, the shepherd, called by Enlil, am I."

Hammurapi law code, I 27-53 (Meek, in ANET p. 164)

It is clear from these phrases that the main function of kingship was to establish justice. An example in the prologue of the Ur-Nammu law code seems to express the same idea as the former examples, although the passage is not clear because part of the following phrase was broken:

$\mathrm{u}_{4}$ an-né den-líl-le dnanna-ar nam-lugal-uriki ${ }^{\mathrm{k}}$-ma mu-na-sum-mu-uša-ba $u_{4}$-ba ${ }^{d}{ }^{\prime}{ }^{d}{ }^{d}$ nammu-ke ${ }_{4}$ dumu-tu-da dnin-sún-ka ama-a-tu ki-ággá-ni-ir níg-si-sá-ni-šè níg?-gi ?-na?-ni-šè [

"After An and Enlil had given the kingship of Ur to Nanna, then did UrNammu, son born of Ninsun, for his beloved houseservant, in accordance with his justice and truth? [

Ur-Nammu law code, 31-42 (Finkelstein, JCS 22, p. 67)(5)

Lipit-Ištar and Hammurapi declared in the first phrase of the epilogue of their respective law codes that they established laws on their own initiative:

inim-gi-na- ${ }^{\mathrm{d}}$ utu-ta ki-en-gi-ki-uri di-gi-na hé-ib-dab ${ }_{5}$ 
"Verily in accordance with the true word of Utu, I caused the Sumerians and Akkadians to hold to true justice."

Lipit-Ištar law code (Steele, $A J A$ 52, p. 444, II' 2'-4')

dināt mǐsarim ša hammurapi šarrum le'ûm ukinnuma

"The laws of justice, which Hammurapi, the efficient king, set up."

Hammurapi law code, XLVII 1-5

We cannot cite examples of Ur-Nammu law code, since the epilogue is missing.

I will compare the law codes with the "reform text" of UruKAgina at the end of the Early Dynastic period. Just before the articles of "reformation" in this text, there is the following expression:

$\mathrm{u}_{4} \quad{ }^{d}$ nin-gír-su ur-sag-d en-líl-lá-ke ${ }_{4} \quad$ uru-KA-gi-na-ra nam-lugal-lagašs ${ }^{\mathbf{k}}$ e-na-sum-ma-a šà-lú-36000-ta šu-ni e-ma-ta-dab ${ }_{5}$-ba-a nam-tar-ra-u bi-ta e-šè-gar inim-lugal-ni dnin-gír-su-ke ${ }_{4}$ e-na-du ${ }_{11}$-ga ba-dab ${ }_{5}$ "When Ningirsu, the warrior of Enlil, gave the kingship of Lagaš to UruKAgina and took his hand from out of those of $36000 \mathrm{men}$, he restored the decrees of former days and he grasped word which Ningirsu, his king, spoke to him."

Ukg. 4, VII 29-VIII 13

The object of his reformation was to restore order and rules which had been established by the gods in the remote past, and he executed the reformation exactly as the god Ningirsu had ordered him to. Then UruKAgina said just after the articles of "reformation":

dnin-gír-su-da uru-KA-gi-na-ke ${ }_{4}$ inim-bi ka e-da-kéš

"UruKAgina made a covenant with Ningirsu for (observance of) the order."

Ukg. 4, XII 26-28

UruKAgina was sensitive to his relationship to the god Ningirsu and obeyed the orders which the god gave him. He never mentions his own initiative in the reformation at all. There are indications in another inscription of UruKAgina that he had to mintain order and rules in his city for the sake of the city-god Ningirsu. 
lú-umma ${ }^{k i}-k_{4}$ egir-lagaški ba-ḩul-a-ta nam-tag dnin-gír-su-da e-daak-ka-am ${ }_{6}$ šu in-ši-DU-a-am ${ }_{6}$ e-ta-ku $u_{5}-\mathrm{ku}_{5}$ nam-tag uru-KA-gi-na lugalgír-su ${ }^{k i}-k a$ nu-gál lugal-zà-ge-si ensí-umma ${ }^{k i}-k a$ dingir-ra-ni ${ }^{d}$ nidaba$\mathrm{ke}_{4}$ nam-tag-bi gú-na hééll-íl

"Because the man of Umma destroyed Lagaš, he committed a sin against Ningirsu. He (Ningirsu) will cut off the hands raised against him. UruKAgina, the king of Girsu, did not commit this sin. May Nidaba, the goddess of Lugalzagesi, the ruler of Umma, make him (Lugalzagesi) bear the sin."

\section{Ukg. 16, VII 10-IX 3}

The destruction of a city is the clearest sign of the absence of city order. The distinctive character of this inscription is described by the following three points: i) The destruction of the city Lagaš was a sin against the city-god Ningirsu. This seems to be based on the idea that a city was the property of the city-god and if someone destroyed the city, his act was regarded as a violation of the rights of the owner of the city (=city-god).

ii) The sin was not attributed to Sara, the city-god of Umma, but rather Lugalzagesi was charged with the sin by his personal goddess Nidaba. A city-god never held himself responsible for the misbehavior of his city ruler. iii) UruKAgina dared to state that he did not commit the sin against Ningirsu. He seems to regard that if a city was destroyed it was due to the ruler's neglect of his duties and he was accordingly blamed for his dereliction. We can assume for this reason that UruKAgina thought that he must behave piously and continually serve the city-god Ningirsu.

The character of rulership presented by UruKAgina stands in sharp contrast to that of the kings who established law codes.

Modern scholars generally consider that the "reformation" of UruKAgina was a forerunner of the law codes. However, in regards to this problem, I think we must examine the phraseological change of nig-si-sá/mišarum during these periods, as Edzard has also said.(6) This paper will examin this change.

It is important to recognize that UruKAgina and kings as law givers had different ideas of rulership. UruKAgina was a pious king who did exactly as the gods ordered, while the latter established laws on their own initiative.

3 The term nig-si-sá appeared at the end of the prologue of the Ur-Nammu Vol. XXI 1985 
law code, followed immediately by the articles of law.

níg-erím níg-á-zi i-dutu ug-gu ḩé-ni-dé níg-si-sá kalam-ma hu-mu-nigar

"I made disappear malevolence, wickedness and grief, I established justice in the land."

Ur-Nammu law code (Yildız, OrNS 50, 88, Obv. II 47-51)

The end of the prologue of the Lipit-Ištar law code is unclear because this part is missing. At the end of the prologue of the Hammurapi law code similar phrases also appeared:

inüma ${ }^{d}$ marduk ana šutēsur nǐš mātim usîm šūhnuzim uwa'iranni kittam u mǐsaram ina pi mätim aškun šir niš̃i uțib

"When Marduk commissioned me to keep good order over the people and to nurture good behavior in the land, I established truth and justice in the land and I promoted the welfare of the people."

Hammurapi law code, V 14-24

We can be certain that the purpose of establishing laws was to establish níg-sisá/mǐsarum "justice" in the human world.

Níg-si-sá stands in opposition to níg-erím, níg-á-zi and i-dutu in the UrNammu law code cited above. This antithesis appeared in the other law cides:

"in order to establish justice in the land, to banish grief (i-d utu), to trun back malevolence (níg-erím) and wickedness (níg-á-zi) into their houses," Lipit-Ištar law code, II 1-6

"in order to cause justice to prevail in the land, to destroy the wicked (raggum) and the evil (șenum),"

Hammurapi law code I 31-36

Níg-si-sá/mț̌arum "justice" refers to "righteousness" in social relationships, and therefore is not the direct antithesis of nam-tag "sin against gods."

We can cite similar examples of níg-si-sá/mtšarum from the inscriptions which were written by kings from Gudea down to Nidnuta: 
$\mathrm{u}_{4}$ níg-si-sá mu-na-ta-è níg-erím ì- ${ }^{\mathrm{d}} \mathrm{utu}$ gú-bi gìr bí-ús

"When justice was rising and malevolence and grief were surrendered," Gudea Cyl. B, XVIII 10-11

níg-si-sá-e pa-è bí-ak níg-erím sá bí-du $u_{11}$

"I made justice resplendent, I removed malevolence,"

Ur-Nammu Hymn 2 (TCL XV, 12, 38)

níg-si-sá-e ki ha-ba-ág-gá-àm níg-erím-e ki la-ba-ra-ág-gá-àm

"Righteousness I cherish, falsehood I do not tolerate,"

Sulgi Hymn A, 23-24

á-tuk sa-gaz nu-mu-un-ak-e kala-ga si-ga lú-ḩun nu-mu-un-ak-e níg-sisá ki-en-gi-ki-uri-a mu-ni-gar su-kalam-ma mu-du $u_{10}$

"The mighty do not perpetrate robbery, and the strong do not make the weaker ones into hirelings, thus you established justice in Sumer and Akkad, and made pleasant (the life of) everybody in the land."

Lipit-Ištar Hymn B, 36-39 (Vanstiphout, JCS 30, 33 ff.)

níg-erím níg-á-zi-da ha-lam-e níg-si-sá mú-mú

"In order to destroy malevolence and wickedness, and to grow justice," Išme-Dagan Hymn 5 (Römer, $S K I Z$ 45, 100)

níg-si-sá ki-ág níg-zi bar-tam-me NE.[RU záḩ] ù-na-a-du ${ }_{11}$

"Loving justice, choosing righteousness, (destroying evil), speak!"

Sin-iddinam (Hallo, in Zikir Sumim 96, 5)

šăkin mišarim muhalliq raggim

"one who establishes justice and destroys the evildoer,"

Nidnuša of Der (YOS IX, 62, 12)

In the period from Gudea to the Old Babylonian times the core meaning of níg-si-sá/mišarum seemed to be righteousness in human relationships, that is, "social justice."

The oldest example of níg-si-sá is in the Gudea inscription cited above. I cannot find any examples of níg-si-sá in materials from the Early Dynastic period. There is only one example of the similar form nám-si-sá in the UrNanše inscription. I am also unable to find an example of mišarum in the Early Dynastic period. Early examples of misarum are found in the inscription of Puzur-Inšušinak, the ruler of Susa who was contemporary with Naram-Sin and Sarkališarri, and in "Cruciform monument" which is assumed to have been forged in a later period under pretence of the Old Akkadian monument. In 
the next part of this paper I will study whether or not these three examples of nám-si-sá and mǐsarum had the meaning of "social justice" as did níg-si-sá/mišarum in the period from the Ur III Dynasty to Old Babylonian times.

4 The following are the contexts in which nám-si-sá and mišarum appeared.

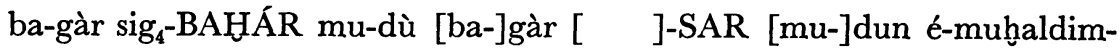
ba-gàr nám-si-sá sum-ma ib-muhaldim-ba-gàr nám-si-sá sum-ma ib-gal mu-dù

"He(Ur-Nanše) built Bagar with bricks. At the Bagar, he dug [ ]: Kitchen(é-muhaldim) of the Bagar which was given nám-si-sá, kitchen (ib-muhaldim) of the Bagar which was given nám-si-sá. He built Ibgal."

Urn. 51, II 3-III 8(?)

J.S. Cooper supposed that nám-si-sá was later replaced by níg-si-sá.(8) Although it is difficult to translate this phrase, nám-si-sá most likely modifies kitchen of the temple. At least, it is possible to say that nám-si-sá does not contrast with níg-erím "molevolence" etc. in this context.

The inscription of Puzur-Inšušinak is as follows:

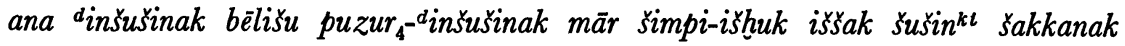
mäti elamtim ${ }^{\imath k}$ [ ] iškunu iškun in bäb-dinšušinak bëlišu u in̄u palag sidrikt iptu șalamšu maharšu ušziz u bābšu sikkat erê gišerēnim iškun

(A-1) 1 immeram in kișim 1 immeram in mehim ümišam ukinšum u narē urri tamhê bāb-dinšušinak ušazmer

(B-1) u 20 šaman ellam ana bābšu dummuqim išruk, 4 MA-GI kaspam išruk, šurinni kaspim u hurāșim erī̌am išruk, 1 patram șiram išruk, 1 hasșsinnam šu 4 $E M E$-šu išruk ušatir, BÀD-si-in kaspam išruk,

ana dinšušinak bēlišu ni-is-ba-at ni-is-ba-at-ma

(B-2) eribšu ul iprus

(A-2) din mišarim (DI.KU $U_{5}$ me-sar-im) in älišu iddin

(A-3) šu dinšu ušbalakkatu

(B-3) $u$ qištašu ițtiru

${ }^{d}$ inšušinak $u^{d}{ }^{d} u t u{ }^{d}$ enlil $u^{d}$ enki dinanna $u^{d}$ suen ${ }^{d}$ ninhursag $u{ }^{d}$ na(run)di naphar ili išdešu lissuhūu u zèrašu lilqutū [ ]

"To the god Inšušinak, his lord; Puzur-Inšušinak, a son of Simpi-išhuk, the governor of Susa, the general of the land of Elam, [

]. .... 
He put it on the gate of Inšušinak, his lord. When he opened the Sidari canal, he placed his statue in front of it (the gate), and he placed a nail of copper and cedar (there).

(A-1) He established for him daily one sheep (offering) at dawn and one sheep (offering) in the evening. He had singers perform day and night at the gate of Inšušinak.

(B-1) He dedicated 20 (measure) of pure oil to embellish the gate. He dedicated 4 - of silver. He dedicated an emblem of silver and gold which was demanded. He dedicated one huge sword. He dedicated one axe with four blades and adorned it. He dedicated -.

To Inšušinak, his lord, -

(B-2) He does not cut off his gifts.

(A-2) He gave a righteous decision to his city.

(A-3) Whoever breaks his decision,

(B-3) and carries off his gifts,

Inšušinak, Utu, Enlil, Enki, Inanna, Suen, Ninhursag and Narundu, and all gods may tear out his foundation and take away his seed. [ ]."

Puzur-Inšušinak inscription (MDP IV, $4 \mathrm{ff}$.)

In this inscription, Puzur-Inšušinak recorded that he placed the statue of Inšusinak in front of the gate, then he instated the rule requiring daily offerings, and dedicated many things to the statue. There is the term din mišarim in this inscription. This term is the same form as dinät mišarim "laws of justice" in the Hammurapi law code. However, if this term is interpreted to mean "law of justice", it seems to be very abrupt in this context written repeatedly about offerings and dedications. It goes without saying that misarum does not contrast with raggum "malevolence" and seenum "wickedness."

I think we can assume that this inscription was constructed from parts (A) and (B) (see above translation). "He gave a righteous decision" (A-2) is paired with "he does not cut off his gifts" (B-2). These gifts refer to the things dedicated, pure oil, emblem, etc. (B-1). On the other hand, "righteous decision" of (A-2) seems to be the rule of the daily offerings of sheep and daily duties of singers (A-1).

Part of the "cruciform monument" concerning mišarum is as follows: 
ana đ̌šamaš bēlija qāti lu ašš šupiti lu išme padān mišarim lu iptiam in ümišuma eqel šuāti ana ūm șâti lu utêr ištim abšan ${ }^{k t}$ adi akšak ${ }^{k t}$ șitt-ď̌amaš durdānum ${ }^{k t}$ $38 \mathrm{URU}^{k t}-U R U^{k t}$ ana ď̆amaš lu uššuru ilikšunu la ahšihu ana šisitim la issušunūšim ilik é-babbar-ma lu illakū

"I lifted my hand to Samaš, my master: he heard my prayer, he opened to me the way of justice. On that very day I returned that field in perpetuity. From Abšan to Akšak east of Durdānum, thirty-eight townships were released unto Šmaš. Indeed, I did not covet their corvée, one did not call them up to service: they perform corvée for the Ebabbar only."

Cruciform munument 108-138 (Sollberger, JEOL 20, 50-70)

In this example mišarum does not contrast with raggum or șēnum. Padān mišarim is rather suggestive of gìr si-sá "to put a road in order" in Lugalzagesi's inscription.

a-ab-ba-sig-\{ta\}-ta idigna-buranun-bi a-ab-ba-igi-nim-ma-šè gìr-bi si e-na-sá

"From the sea below, along the Tigris and Euphrates to the sea above, the roads were put in order."

\section{Lugalzagesi 1, II 4-11}

In this phrase of Lugalzagesi's inscription he seems to be describing that he made the roads safe for travellers. This description may symbolize that his kingdom was in a state of peace.(9) Padān mišarim in "cruciform monument" seems to have the same meaning and to be related to the following phrase in the text. It seems to me that this term denoted symbolically the peaceful territory held by the god Samaš. It is difficult to interpret mišarum of this text as "social justice."

This examination cannot furnish positive proof that nám-si-sá and mišarum in the periods of the Early Dynasty and Akkadian Dynasty meant "social justice."

In order to comprehend fully the meaning of nám-si-sá and mišarum in early times, I think it is useful here to cite the function of the god Lugal-si-sá, whose function was described in Gudea Cylinder B: 
nam-šita ki-lagaš $^{\mathbf{k i}}$ šu-du ${ }_{8}$-a-da siskur ${ }_{x}-r a ́-z u-b i ~ d u_{10}$-ga gá-gá-da ursag erida ${ }^{k i}$-šè gin-a-ni silim-ma-du ${ }_{10}$ di-da ${ }^{d}$ nin-gír-su erida ${ }^{k i}$-ta ginni uru-dù-a gišgu-za-bi gi-na nam-ti sipa-zi gù-dé-a-da kiri ${ }_{x}$-šu-gál-lada ad-gi ${ }_{4}$-gi ${ }_{4}$-ni dugal-si-sá en- ${ }^{\mathrm{d}}$ nin-gír-su me-ni-da mu-na-dib-e "In order to guarantee prayers in all the districts of Lagaš, to make offerings and prayers good, to say "Bon Voyage" to the hero who goes to Eridu, to set up the throne in the city for Ningirsu who comes back from Eridu, to pray kiri-šu-gál-prayer with Gudea for the destiny of the faithful shepherd, his adviser, Lugalsisa takes his ME for the lord Ningirsu." Gudea Cyl. B, VIII 10-22

This god performed duties such as keeping rituals in order, making offerings good and maintaining the safety of roads. These functions of the god are associated with the term si-sá which composes a part of the name Lugal-si-sá.

There are many examples of si-sá in Gudea's inscriptions. First, si-sá means "righteous." It is equivallent to the meaning of nig-si-sá "social justice" in the law codes.

lú lú-si-sá níg-erím-ak-gin 7

"Like the man who does wrong to a righteous man,"

Gudea St. B, IX 24

zi-du-e šu-si-sá-da erím-du-e gú giš gá-gá-da

"to take care of the honest man righteously, and to beat the evil man,"

Gudea Cyl. B, VI 11-12

Si-sá means simply "to prepare" in the following example:

$\mathrm{gu}_{4}$-e šu-_dul-la si-sá-a-da

"He prepared correctly yokes for the oxen."

Gudea Cyl. B, XV 10

There are other examples of si-sá meaning "to prepare correctly offerings and sacrifice" which are equivalent to the functions of Lugalsisa.

$\mathrm{gu}_{4}-\mathrm{du} \mathrm{u}_{7}$ máš-du $\mathrm{u}_{7}$-rá si im-sá-sá-e

"He prepares correctly a perfect bull and a perfect goat (for sacrifice)." 
Gudea Cyl. A, I 14

eme-gír mi-tum giša-ma-ru ḩur-ra-tum giš-ḩur-mè-bi si-sá-sá-a-da "For eme-gir weapon, mitum weapon, amaru weapon and hurratum weapon, he makes correct the rule (in order to fulfil their functions) for battle."

Gudea Cyl. B, VII 14-15

ti-gi níg-du ${ }_{10}$-ge si-sá-a-da

"He prepares correctly the good tigi-instrument."

Gudea Cyl. B, X 9

šà-ba níg-mussa dba-Ú nin-a-na-ke ${ }_{4}$ si ba-ni-sá-sá

"In the temple, he prepared correctly wedding gifts for the goddess $\mathrm{BaU}$, his queen."

Gudea St. D, III 2

Forthermore, si-sá means "to put the divine rule and prayer in order."

šu-luh̆ si bí-sá

"He put suluh-prayer in order."

me-e šu si im-ma-sá

Gudea Cyl. A, X 8

"He put divine rule in order."

Gudea Cyl. A, XX 22

é-a den-ki-ke ${ }_{4}$ giš-ḩur-bi si mu-na-sá

"Enki put the ground plan of the pemple in order."

Gudea Cyl. A, XVII 17

é-e dasar-re šu si ba-sá

"Asar put the temple in order."

Gudea Cyl. B, IV 1

lú pi-lu ${ }_{5}$-da-dingir-re-ne-ke $e_{4}$ si bí-sá-sá-a

"man who put the orders of gods aright,"

Gudea St. R, I 6-7

With due regard to the functions of Lugalsisa and the meaning of si-sá in Gudea's inscriptions, I will go back to an examination of nám-si-sá and mišarum in the Early Dynastic period and the Old Akkadian period.

If we infer the meaning from the context, nám-si-sá in the phrase "kitchen 42 
of the Bagar which was given nám-si-sá" in Ur-Nanše's inscription can be interpreted as "enough preparation of food to satisfy the god."

Din mišarim in Puzur-Inšušinak's inscription can be interpreted as "righteous decision" = "the rule of the daily offerings and order of rituals," as I had already supposed.

I have assumed that padān mišrim in the cruciform monument means "a road which was made safe." This interpretation seems appropriate.

We cannot find examples of níg-si-sá in Early Dynastic and Old Akkadian texts. There is a similar term nám-si-sá in Ur-Nanše's inscription. This term is derived from si-sá and it means "to prepare correctly offerings and sacrifice." Mišarum in Old Akkadian texts is derived from ešerum and shares its broad meaning. It is difficult to restrict the meaning of the terms nám-si-sá and mǐsarum to only "social justice." Rulers in the period before the Akkadian Dynasty understood that 'righteousness' as was indicated by nám-si-sá and misarum meant that they must piously perform their duties without mishap for the sake of the gods. They principally paid attention to righteousness in their relationship to the gods.

5 First I examined how the attitudes of kings differed between UruKAgina in the Early Dynastic period and the rulers as law givers, Ur-Nammu, LipitIštar and Hammurapi, and then the difference in the meaning of nám-si-sá and mišarum.

In the period before the Akkadian Dynasty, rulers sought righteousness through pious behavior for the sake of the gods. On the other hand, the rulers in the period after the Ur III Dynasty recognized "social justice" in human relationships, although the image of the pious king continued as a basic principle of the kingship. This shift in ideas was based on a change from people being totally controlled by the rule of the gods to people becoming conscious of their inter-personal relationships. With this change they made their society independent to some degree from the divine world.

Ur-Nammu declared that he was a protective genius:

ur- ${ }^{\mathrm{d}}$ nammu lugal-uríki ${ }^{\mathbf{k}}$-ma dama-uru-gá-me-en

"I, Ur-Nammu, king-of Ur, am protective genius of my city."

Ur-Nammu Hymn 2 (TCL XV, 12, 31) 
Following this phrase, he wrote that he destroyed evils and made righteousness prosper. The king placed himself at the top of human society and was thus on the same level with the gods. Conversely he was far removed from his people. He held the position of abslute kingship. Kings in the period from the Ur III Dynasty onward established law codes on their own initiative, in order to consolidate their reign over the people. On the other hand, the reform of UruKAgina in the Early Dynastic period had as its object to preserve the city rules which the god Ningirsu laid down. UruKAgina performed his duties as king according to his understanding of the old idea of kingship, "pious king".

The idea of "king is a shepherd" seems to help strenghten the character of the king as law giver. In the law codes of Lipit-Ištar and Hammurapi mentioned above, when they were given the kingship in order to establish social justice, they were designated as shepherd (sipa, $r \ddot{e}^{\prime} \hat{u} m$ ). These kings lead crowds of people in the right direction, like a shepherd leads a flock of sheep.

The idea of the shepherd-king had already appeared in the Early Dynastic period. A personal name "Enannatum is true shepherd (en-an-na-túm-sipazi)" appeared in two texts of Enentarzi of Lagaš. (10) UruKAgina wrote about himself:

dba-Ú HÉ-GAM + GAM-uru-kù-ga-ke ${ }_{4}$ uru-KA-gi-na nam-sipa-še mu-tu "The goddess $\mathrm{BaU}$, the ... of Uruku, bore UruKAgina suitable for shepherd."

Ukg. 51

Lugalzagesi also wrote about himself:

sipa sag-GU, !-gál da-rí ḩé-me

"Unto eternity may I be shepherd, ...."

Lugalzagesi 1 , III $35-36$

The idea of the shepherd-king was useful to strengthen the king's authority. Independence of human society from the divine world prepared new ground for the development of kingship. It seems to me, however that the growing organization of the kingship hindered the development of a human society which might have eventually arrived at a stage of individualism and rationslism that we find in ancient Greek society. Sumerian myths related that human 
beings were created in order to serve gods. (11) They could not sever their connections with the gods. For this reason, human society of Sumer did not completely attain their independence from the divine world. According to the pro-kingship idea people must be the servants of gods and kings who had the authority of gods.

\section{Notes}

(1) T. Maeda, "King of Kish" in Pre-Sargonic Sumer, Orient 17 (1981) 1-17. idem, "King of the Four Regions" in the Dynasty of Akkade, Orient 20 (1984), 67-82.

(2) It can be assumed concerning the political situation of the second half of the Early Dynastic III period that the royal title lugal-ŠAR.DIS, used by the rulers of Umma and Lugalkisalsi of Uruk, was intended to mean not only "king of Umma," but also "king of the world." It was never used by later rulers and disappeared. It seems to me that this title reflected another effort at unification over the Sumerian city-states.

(3) M.-J. Seux, Epithethes royales akkadiennes et sumeriennes, Paris, 1967. W. W. Hallo, Early Mesopotamian Royal Titles: A Philologic and Historical Analysis, New Haven, 1957.

(4) S. N. Kramer, The Ur-Nammu Law Code: Who Was Its Auther? OrNS 52/4 (1983) 455 , n. 14.

(5) Cf. S. N. Kramer, OrNSS 52/4, 455 \& n. 11.

(6) D. O. Edzard, 'Soziale Reformen' im Zweistromland bis ca. 1600 v. Chr.: Realität oder literarischer Topos? in J. Harmatta and G. Komoróczy(ed.), Wirtschaft und Gesellschaft im alten Vorderasien, Budapest, 1976, 153.

(7) H. Steible, Die altsumerischen Bau- und Weihinschriften II, Wiesbaden, 1982, 18 n. 3. n. 5 .

(8) J. S. Cooper, Studies in Mesopotamian Lapidary Inscriptions II, RA 74 (1980), 108,

(9) D. Frayne, Sulgi, the Runner, JAOS 103/4 (1983) 739-748.

(10) Enz 1 (letter). Cros, NFT p. 181: $A O 4156$.

(11) "The Creation of Man" (Ebeling, KAR, n. 4, 26-27), "Enki and Ninmah" (Benito, "Enki and Ninmah" and "Enki and the World Order," Ph. D. diss. 1969, p. 24, 1. 30). Cf. Enuma Eris VI 6-9, and Atra Hasis, Texts G. and V. 